\title{
Atypical Presentation of Salzmann Nodule: A Case Report and Literature Review
}

Mohanna Y. Aljindan ${ }^{1}$, Malak A. Bamashmoos ${ }^{2}$, Reem A. AlShamlan ${ }^{3}$, Amal A. AlOdaini ${ }^{4}$, Hanoof A. Alabdullatif ${ }^{4}$

1. Ophthalmology, King Fahd University Hospital, Imam Abdulrahman Bin Faisal University, Dammam, SAU 2. Ophthalmology, Dahran Eye Specialist Hospital, Dammam, SAU 3. Ophthalmology, College of Medicine, Imam Abdulrahman Bin Faisal University, Dammam, SAU 4. Histopathology, King Fahd University Hospital, Imam Abdulrahman Bin Faisal University, Dammam, SAU

Corresponding author: Malak A. Bamashmoos, malak.bamashmoos@hotmail.com

\begin{abstract}
Salzmann's nodular degeneration (SND) is an unusual corneal condition that is slowly progressive and noninflammatory in nature. It results in millimetric gray-white to bluish nodules formation anterior to Bowman's layer of the cornea. It usually affects both eyes in $80 \%$ of the cases. These elevated nodules are located near the limbus or in the mid-peripheral cornea, with some exceptions. Salzmann nodule develops following corneal trauma or inflammation. However, it can present idiopathically.
\end{abstract}

Here, we report an atypical case of idiopathic symptomatic large central SND that was treated successfully with superficial keratectomy.

Categories: Ophthalmology

Keywords: atypical salzmann, salzmann nodular degeneration, literature review, central salzmann, visually significant salzmann

\section{Introduction}

Salzmann's nodular degeneration (SND) is an unusual corneal condition that is slowly progressive and noninflammatory in nature. It results in millimetric gray-white to bluish nodules formation anterior to Bowman's layer of the cornea [1]. It usually affects both eyes in $80 \%$ of the cases [2]. These elevated nodules are located near the limbus or in the mid-peripheral cornea with some exceptions. Salzmann nodule develops following corneal trauma or inflammation. However, it can present idiopathically [1,3-5].

Review began 05/13/2021 Review ended 05/31/2021 Published 06/02/2021

๑) Copyright 2021

Aljindan et al. This is an open access article distributed under the terms of the Creative Commons Attribution License CC-BY 4.0., which permits unrestricted use, distribution, and reproduction in any medium, provided the original author and source are credited.
In this report, we present a case of an atypical Salzmann nodule located in the center of the cornea covering the visual axis for which it was treated surgically.

\section{Case Presentation}

A 54-year-old Saudi male patient, who is unknown to have any medical illness presented to the ophthalmology clinic complaining of decreased vision in both eyes, more pronounced in the left eye for two years that was getting progressively worse in the last five months. He denied any previous ocular infection or trauma and never used contact lenses. The patient did not undergo any ocular surgery nor used any eye drops. His examination revealed visual acuity of 0.15 (in decimal) $(20 / 200)$ in the right eye and hand motion in the left eye. The slit-lamp examination of the right eye showed multiple peripheral sup-epithelial round whitish lesions, and the left cornea showed a single central lesion (Figure 1). A cross-sectional photo of anterior segment optical coherence tomography (OCT) of the same eye showed a central hyper-reflective corneal lesion that is confined to the subepithelial layer (Figure 2). The clinical impression was left corneal keloid or Salzmann's nodule. Superficial keratectomy with manual excision of the lesions was done for both eyes as means of treatment and to compare the samples (Figures 3, 4). The patient's vision improved postoperatively; it reaches $0.2(20 / 100)$ in the right eye and $0.3(20 / 60)$ in the left eye. Histologically, the cornea demonstrated thinned epithelium overlaying the nodule with fibroblastic proliferation and deposition of extracellular hyalinized material. Neither an inflammatory infiltrate nor hemosiderin deposits were identified. Descemet membrane and endothelium were not present in the specimen. These findings, although non-specific, are consistent with the clinical diagnosis of Salzmann's nodule (Figure 5). 


\section{Cureus}

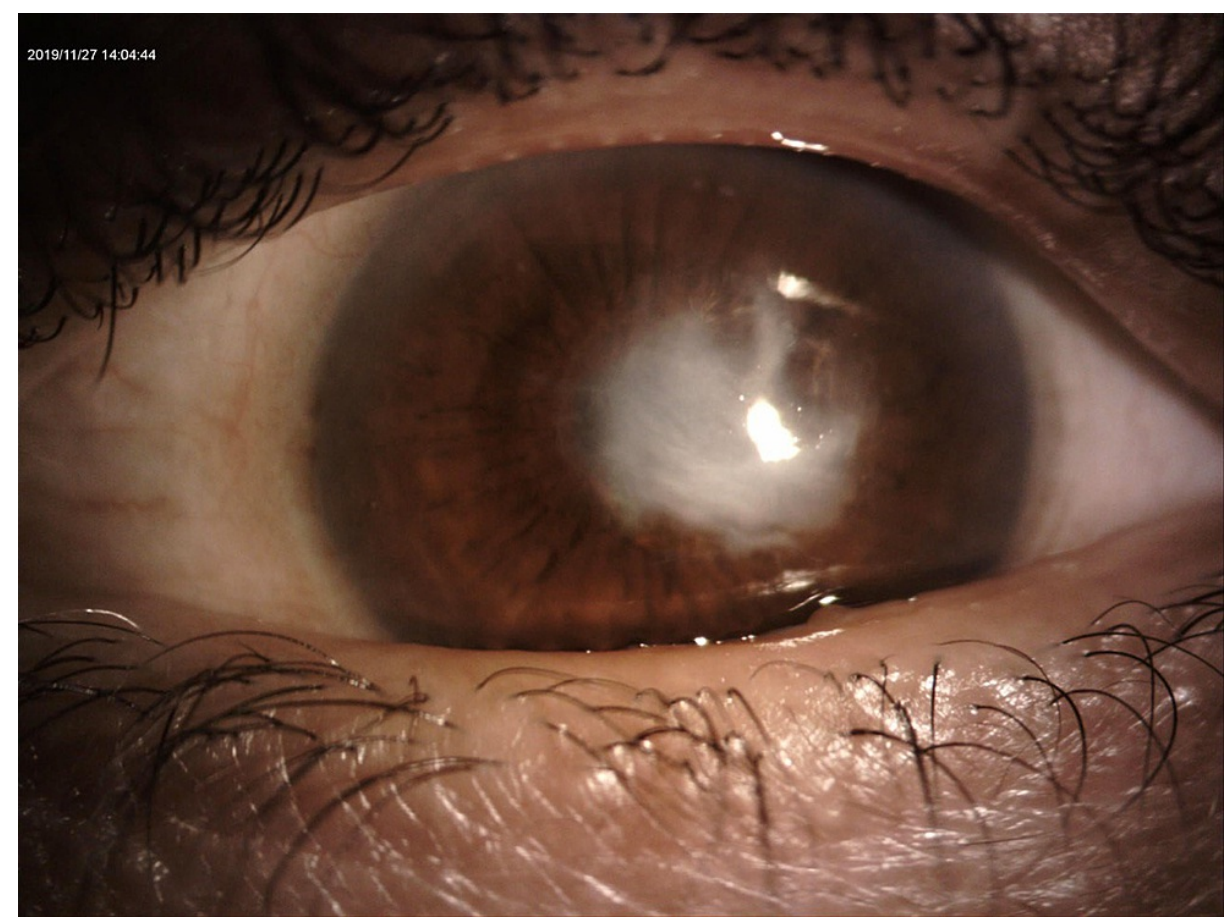

FIGURE 1: Slit lamp photo of the left eye showing large central elevated whitish lesion 


\section{Cureus}

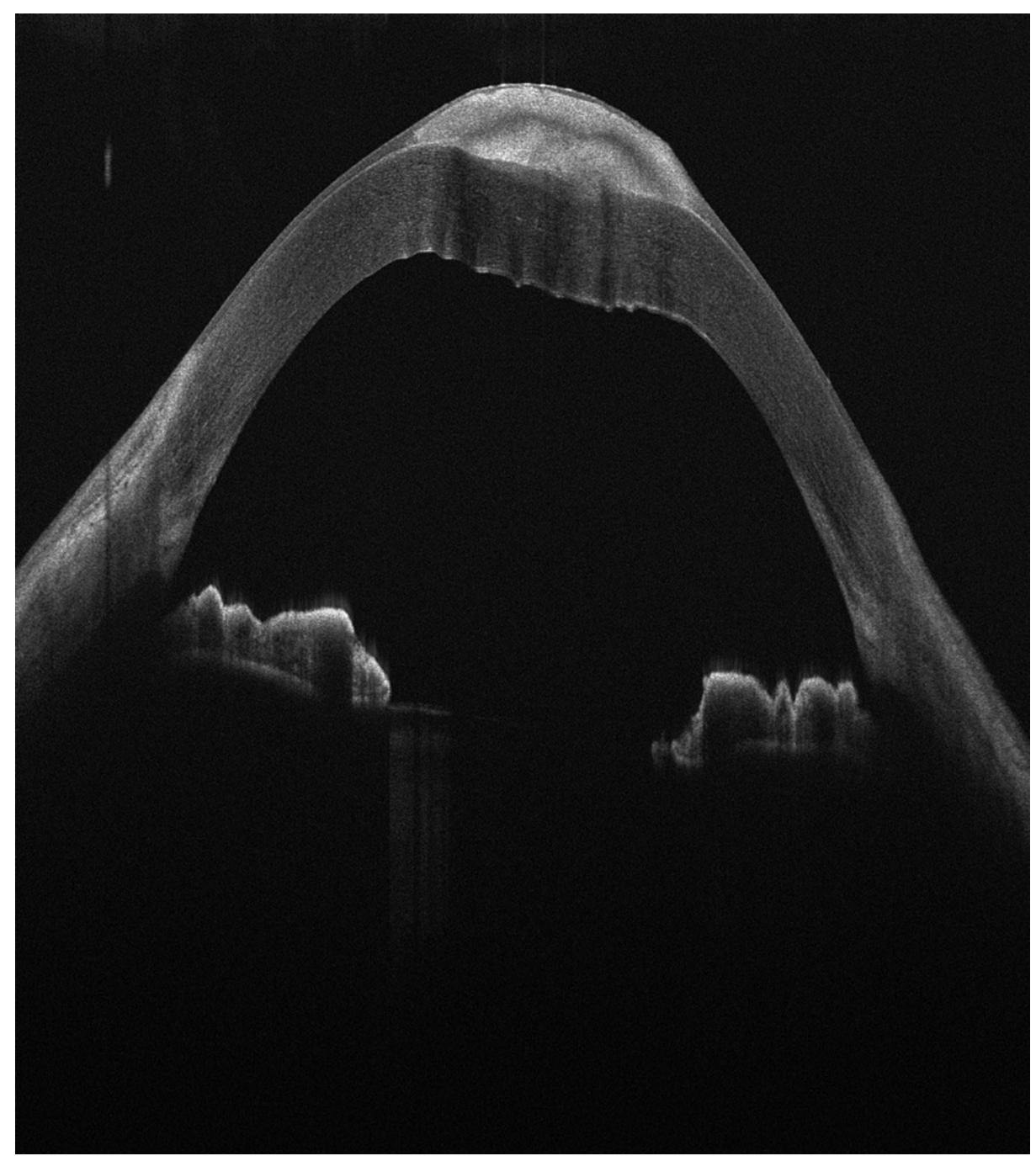

FIGURE 2: OCT showing hyper-reflective sub-epithelial lesion anterior to the Bowman's layer 


\section{Cureus}

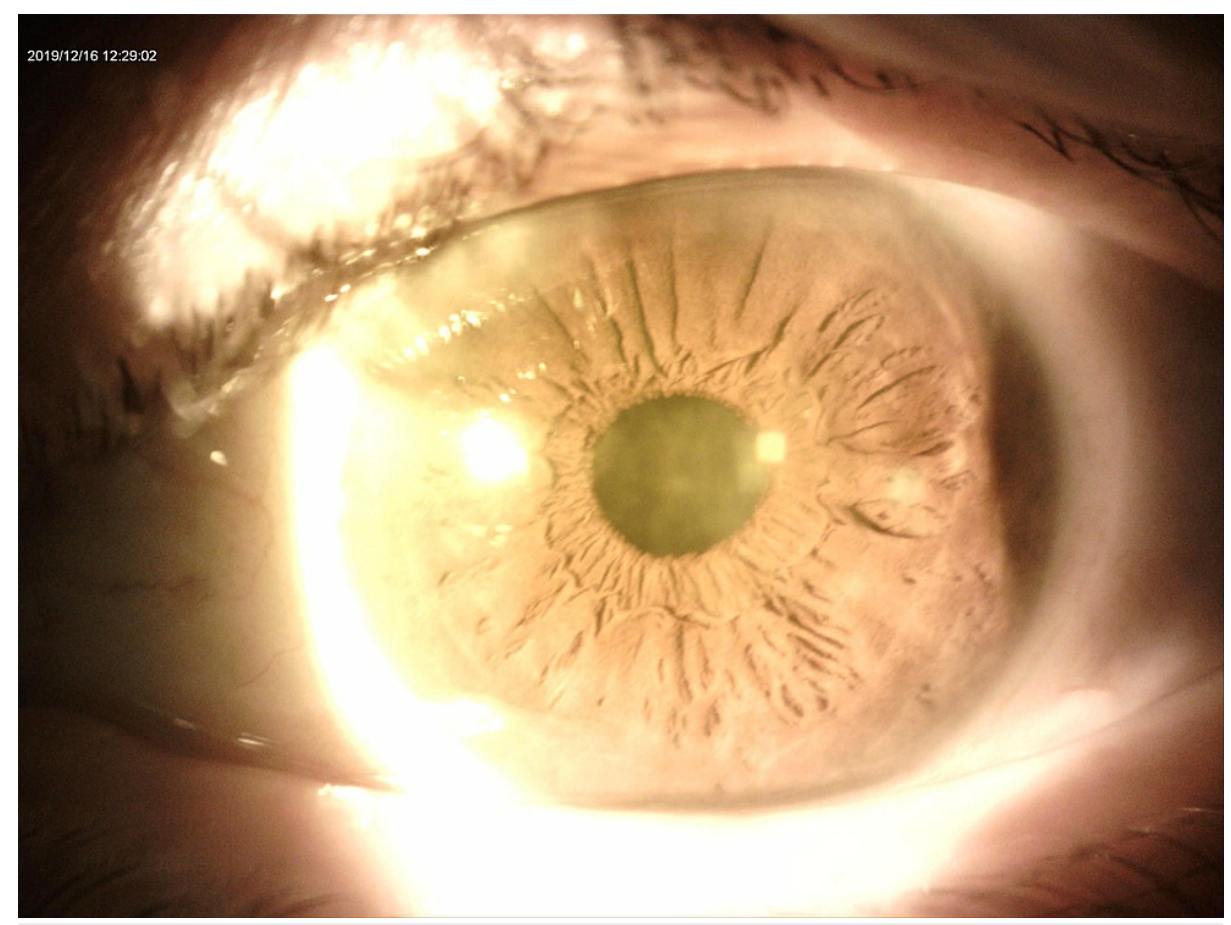

FIGURE 3: Slit lamp photo of the cornea after excision of the lesion with mild haze 


\section{Cureus}

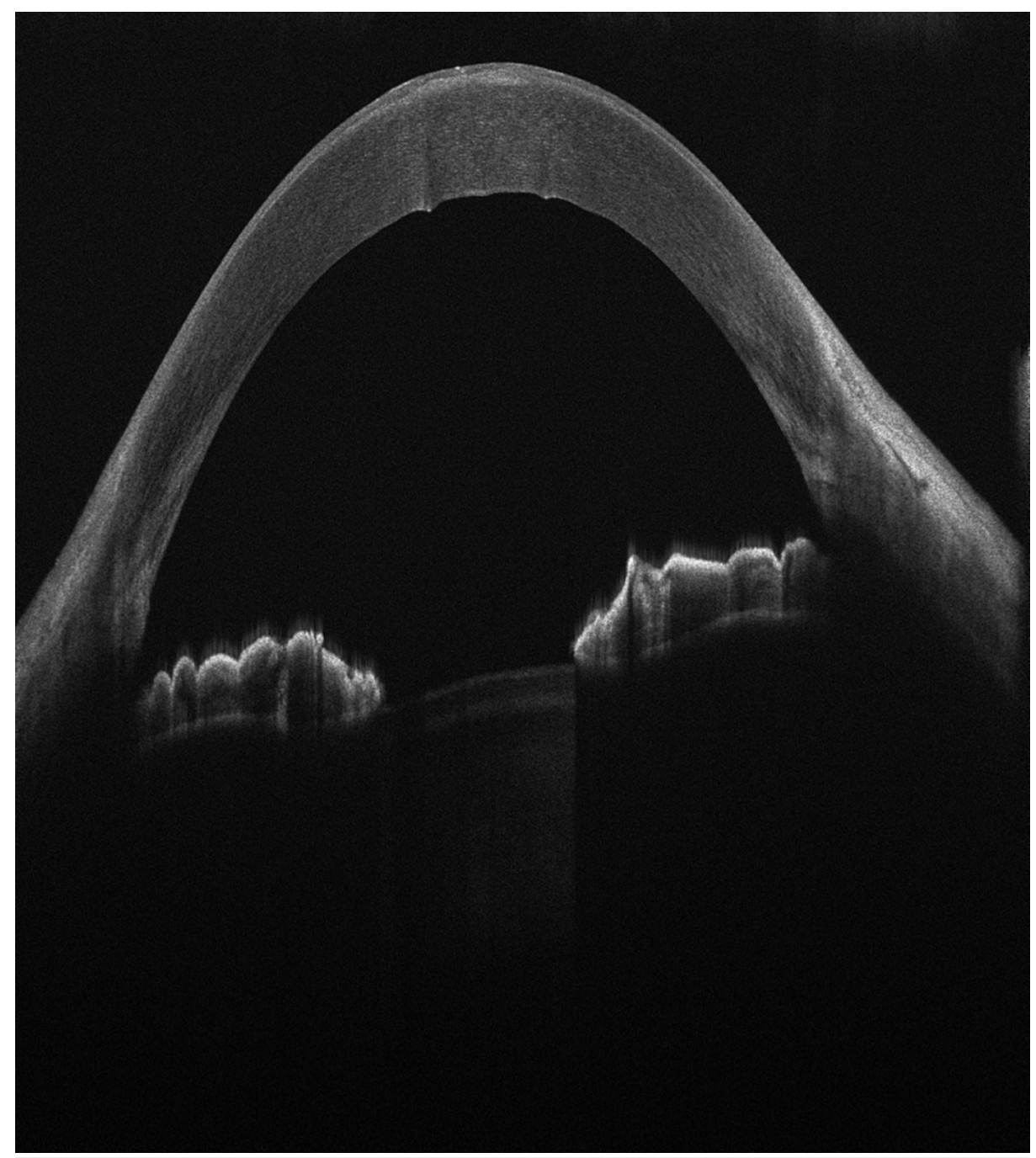

FIGURE 4: OCT of the cornea after excision of the lesion 


\section{Cureus}

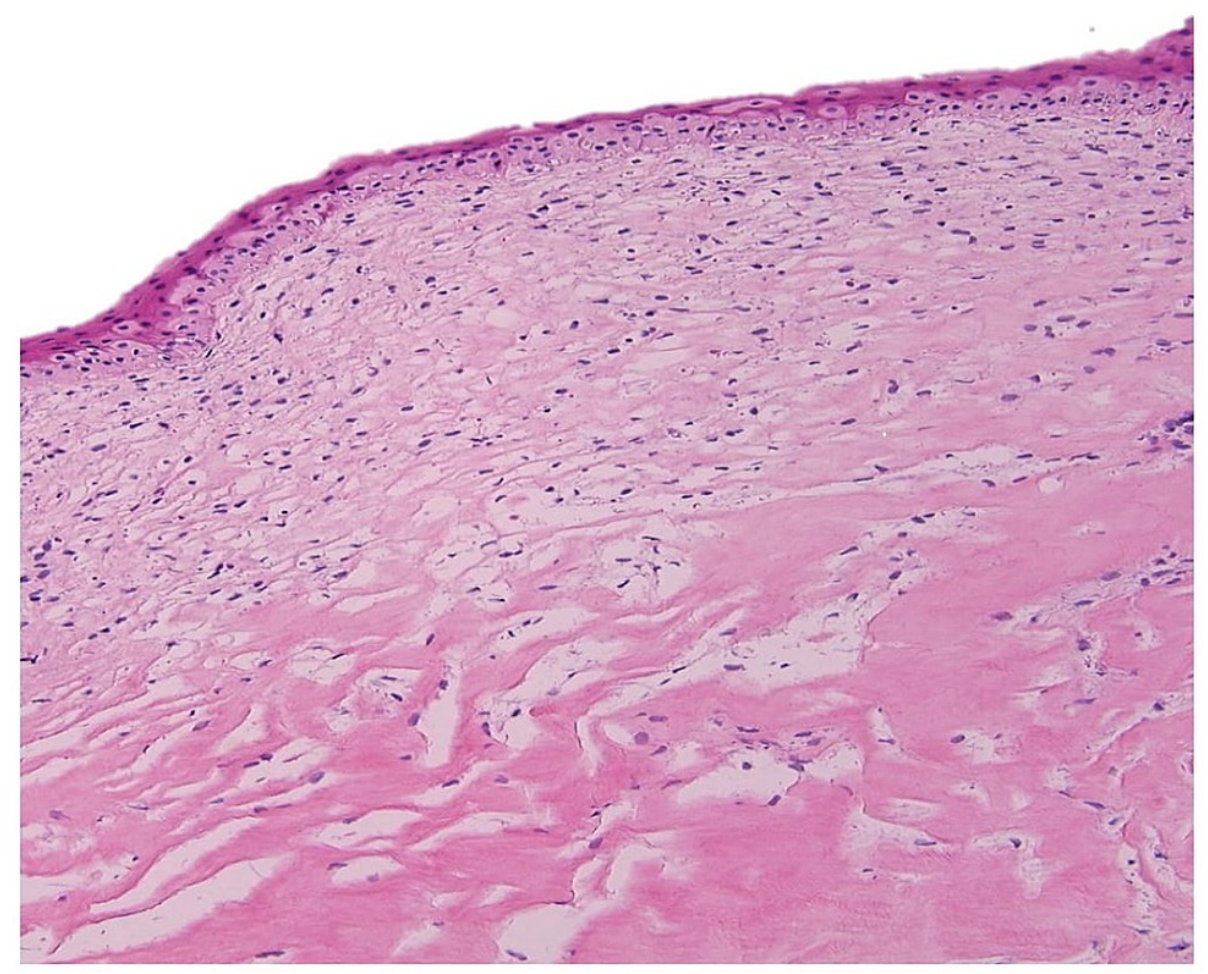

FIGURE 5: Histopathologic examination shows thinning of the corneal epithelial lining with sub-epithelial fibroblastic proliferation and deposition of hyalinized material (hematoxylin and eosin $\times 100$ )

\section{Discussion}

SND usually presents as symmetrical bilateral nodules located more commonly in the periphery of the cornea $[4,5]$. Our patient had asymmetric nodules bilaterally with an atypical central, visually significant nodule in the left eye.

SND was first described in 1925 by Maximilian Salzmann as multiple or solitary bluish-white corneal nodular elevation. Then it was named in 1930. Multiple studies followed his series to describe and understand the disease more [6,7]. Although the pathogenesis of SND is still unknown, recent studies have shown that there is a major role in metabolically active basal cells of the nodular epithelium [8].

SND is typically associated with chronic corneal disorders, meibomian gland dysfunction, contact lens wear, surgical procedure, traumatic injury of the cornea, peripheral vascularization, pterygium,

keratoconjunctivitis sicca, or inflammatory diseases like Crohn's disease. However, several cases of SND presented without any previous ocular diseases as seen in our patient $[3,8,9]$. SND usually affects females. A retrospective study conducted between 1996 and 2002 showed that $89.2 \%$ of patients with SND were female [9]. SND can be presented with decreased visual acuity, epiphora, photophobia, foreign body sensation, or asymptomatically in $15 \%$ of cases $[4,8]$.

Histologically, the findings of SND include the presence of subepithelial fibrosis, fibroblastic degeneration, absent or disrupted bowman's layer, deposition of extracellular matrix, and attenuated overlying corneal epithelium $[6,10,11]$. These findings were similar to what was found in our case. The histopathologic features are nonspecific and the diagnosis of (SND) should be made with clinical correlation [4,10-12].

Salzmann's nodule is managed conservatively or surgically depending on the patient's presentation. Conservative management includes treating known underlying causes, proper hygiene, warm compressor, lubricant, and steroid drops [4]. Most patients benefit from medical treatment alone. However, there are some indications for surgical interventions like; decreased visual acuity or foreign body sensation [13]. Superficial keratectomy alone or with alcohol, mitomycin-C, or amniotic membrane transplant were documented in the literature as surgical options. Lamellar keratoplasty is rarely needed [5]. Around $90 \%$ of patients will have an improvement in visual acuity after surgical intervention [14]. In our case, Salzmann's nodule was centrally located in the left eye and affecting the vision. Therefore, superficial keratectomy was done to clear the visual axis. The recurrence of SND is increasing with longer follow-up [9]. Most commonly, 


\section{Cureus}

patients take five to 15 years to develop SND again. However, visually significant Salzmann nodule is uncommon as it affects $5 \%$ to $20 \%$ of those with the recurrence $[9,14]$. Table 1 summarizes cases documented in the literature.

\begin{tabular}{|c|c|c|c|c|}
\hline Reference & Case & Previous history & Location & Management \\
\hline $\begin{array}{l}\text { Garg, } \\
\text { Sharma, \& } \\
\text { Khan (2019) } \\
{[15]}\end{array}$ & A case report of a 50 -year-old male & $\begin{array}{l}\text { Medically free, } \\
\text { presented with a } \\
\text { progressive decrease in } \\
\text { vision }\end{array}$ & $\begin{array}{l}\text { Paracentral } \\
\text { extending } \\
\text { centrally, } \\
\text { unilateral }\end{array}$ & Superficial keratectomy \\
\hline $\begin{array}{l}\text { Yang, Al- } \\
\text { Hashimi, \& } \\
\text { Rootman } \\
\text { (2018) [16] }\end{array}$ & A case report of $30-$ year- old female & $\begin{array}{l}\text { Hyperthyroidism and } \\
\text { post uncomplicated } \\
\text { LASIK eight years back }\end{array}$ & $\begin{array}{l}\text { Peripheral, } \\
\text { bilateral } \\
\text { Tearing, } \\
\text { itching, ocular } \\
\text { surface } \\
\text { sensitivity, and } \\
\text { dry eyes }\end{array}$ & $\begin{array}{l}\text { Medical treatment d } \\
\text { propylthiouracil (PTU), } \\
\text { artificial tear use, } \\
\text { loteprednol etabonate } \\
\text { ophthalmic gel, eyelid } \\
\text { taping, and selenium } \\
\text { supplementation }\end{array}$ \\
\hline $\begin{array}{l}\text { Stem \& Hood } \\
\text { (2015) [17] }\end{array}$ & A case report of a 41-year-old female & $\begin{array}{l}\text { Post uncomplicated } \\
\text { LASIK for myopia }\end{array}$ & $\begin{array}{l}\text { Peripheral } \\
\text { unilateral with } \\
\text { epithelial } \\
\text { ingrowth } \\
\text { centrally but } \\
\text { not invade the } \\
\text { visual axis }\end{array}$ & Superficial keratectomy \\
\hline $\begin{array}{l}\text { Lange, Bahar, } \\
\text { Sansanayudh, } \\
\text { Kaisermann, } \\
\text { \& Slomovic } \\
\text { (2009) [18] }\end{array}$ & A case of a 50 -year-old female & $\begin{array}{l}\text { Progressive vision } \\
\text { reduction for several } \\
\text { years. Medical history of } \\
\text { Crohn's disease on } \\
\text { infliximab with no eye } \\
\text { involvement }\end{array}$ & $\begin{array}{l}\text { Bilateral. } \\
\text { Midperipheral }\end{array}$ & $\begin{array}{l}\text { Visual field was not } \\
\text { affected, follow up only }\end{array}$ \\
\hline $\begin{array}{l}\text { Sinha, } \\
\text { Chhabra, } \\
\text { Vajpayee, } \\
\text { Kashyap, \& } \\
\text { Tandon } \\
\text { (2006) [19] }\end{array}$ & $\begin{array}{l}\text { Two case report: 1-Recurrent Salzmann's } \\
\text { nodule of } 40 \text {-year-old male following } \\
\text { keratoplasty in both eyes, } 22 \text { years ago. 2- } \\
\text { Recurrent Salzmann's nodule or } 24 \text {-year- } \\
\text { old male following keratoplasty in both } \\
\text { eyes, six years ago. }\end{array}$ & $\begin{array}{l}\text { Chronic trachoma and } \\
\text { continued exposure to } \\
\text { dust, wind and sunlight, } \\
\text { probably were the } \\
\text { predisposing factors. }\end{array}$ & $\begin{array}{l}\text { Central } \\
\text { bilateral }\end{array}$ & Treated with keratoplasty \\
\hline $\begin{array}{l}\text { Das, Link, \& } \\
\text { Seitz (2005) } \\
\text { [1] }\end{array}$ & Case series of 30 eye & $\begin{array}{l}\text { Five previous Keratitis, } \\
\text { one ocular Trauma }\end{array}$ & $\begin{array}{l}40 \% \text { peripheral } \\
60 \% \\
\text { paracentral } \\
\text { and central }\end{array}$ & $\begin{array}{l}\text { Eight asymptomatic no } \\
\text { surgical or medical } \\
\text { intervention. } 22 \text { with } \\
\text { abnormal visual acuity } \\
\text { treated by PTK }\end{array}$ \\
\hline $\begin{array}{l}\text { Swann \& } \\
\text { Shuley (1989) } \\
{[20]}\end{array}$ & A case report of a 32 -year-old male & Vernal conjunctivitis & $\begin{array}{l}\text { Unilateral } \\
\text { peripheral }\end{array}$ & $\begin{array}{l}\text { Asymptomatic did not } \\
\text { require any treatment }\end{array}$ \\
\hline $\begin{array}{l}\text { Katz (1930) } \\
{[7]}\end{array}$ & A case report of a 38-year-old female & $\begin{array}{l}\text { Recurrent history of } \\
\text { inflammation since the } \\
\text { age of } 14 \text {-year-old } \\
\text { increases in severity at } \\
\text { age of } 32 \text {. (eczematous } \\
\text { keratoconjunctivitis) }\end{array}$ & $\begin{array}{l}\text { Unilateral } \\
\text { peripheral }\end{array}$ & $\begin{array}{l}\text { Mild mercurous chloride } \\
\text { insufflation, mercuric } \\
\text { oxycyanide }(1: 3,000) \text {, one } \\
\text { drop three times a day, and } \\
\text { yellow mercuric oxide } \\
\text { ointment }(3 \%) \text {, nightly }\end{array}$ \\
\hline
\end{tabular}

TABLE 1: Cases documented in the literature

Conclusions

This report highlights an unusual presentation of SND of a central idiopathic nodule affecting the vision. Superficial keratectomy for histopathologic examination can be very supportive in diagnosing atypical cases with large or central nodules. 


\section{Additional Information \\ Disclosures}

Human subjects: Consent was obtained or waived by all participants in this study. Conflicts of interest: In compliance with the ICMJE uniform disclosure form, all authors declare the following: Payment/services info: All authors have declared that no financial support was received from any organization for the submitted work. Financial relationships: All authors have declared that they have no financial relationships at present or within the previous three years with any organizations that might have an interest in the submitted work. Other relationships: All authors have declared that there are no other relationships or activities that could appear to have influenced the submitted work.

\section{References}

1. Das S, Link B, Seitz B: Salzmann's nodular degeneration of the cornea: a review and case series . Cornea. 2005, 24:772-7. 10.1097/01.ico.0000153100.74033.ef

2. Vannas A, Hogan MJ, Wood I: Salzmann's nodular degeneration of the cornea. Am J Ophthalmol. 1975, 79:211-9. 10.1016/0002-9394(75)90074-4

3. Roszkowska AM, Aragona P, Spinella R, Pisani A, Puzzolo D, Micali A: Morphologic and confocal investigation on Salzmann nodular degeneration of the cornea. Invest Ophthalmol Vis Sci. 2011, 8:5910-9. 10.1167/iovs.11-7789

4. Hamada S, Darrad K, McDonnell PJ: Salzmann's nodular corneal degeneration (SNCD): clinical findings, risk factors, prognosis and the role of previous contact lens wear. Cont Lens Anterior Eye. 2011, 34:173-8. 10.1016/j.clae.2011.02.004

5. Paranjpe V, Galor A, Monsalve P, Dubovy SR, Karp CL: Salzmann nodular degeneration: prevalence, impact, and management strategies. Clin Ophthalmol. 2019, 13:1305-14. 10.2147/OPTH.S166280

6. Meltendorf C, Bühren J, Bug R, Ohrloff C, Kohnen T: Correlation between clinical in vivo confocal microscopic and ex vivo histopathologic findings of Salzmann nodular degeneration. Cornea. 2006, 25:7348. 10.1097/01.ico.0000214215.75496.a5

7. Katz D: Salzmann's nodular corneal dystrophy. Report of a case . Arch Ophthalmol. 1930, 4:16-21. 10.1001/archopht.1930.00810090024002

8. Eberwein P, Hiss S, Auw-Haedrich C, et al.: Epithelial marker expression in Salzmann nodular degeneration shows characteristics of limbal transient amplifying cells and alludes to an involvement of the epithelium in its pathogenesis. Acta Ophthalmol. 2010, 88:184-9. 10.1111/j.1755-3768.2010.01887.x

9. Farjo AA, Halperin GI, Syed N, Sutphin JE, Wagoner MD: Salzmann's nodular corneal degeneration clinical characteristics and surgical outcomes. Cornea. 2006, 25:11-5. 10.1097/01.ico.0000167879.88815.6b

10. Qiu J, Cai R, Zhang C: Association between poor wound healing and the formation of Salzmann nodules . J Cataract Refract Surg. 2016, 42:1527-30. 10.1016/j.jcrs.2016.07.019

11. Stone DU, Astley RA, Shaver RP, Chodosh J: Histopathology of Salzmann nodular corneal degeneration. Cornea. 2008, 27:148-51. 10.1097/ICO.0b013e31815a50fb

12. Yoon KC, Park YG: Recurrent Salzmann's nodular degeneration. Ipn J Ophthalmol. 2003, 4:401-4. 10.1016/s0021-5155(03)00044-3

13. Graue-Hernández EO, Mannis MJ, Eliasieh K, Greasby TA, Beckett LA, Bradley JC, Schwab IR: Salzmann nodular degeneration. Cornea. 2010, 29:283-9. 10.1097/ICO.0b013e3181b7658d

14. Carroll JN, Maltry AC, Kitzmann AS: Salzmann's nodular corneal degeneration: 62-year-old woman presents with 3 years of progressive decrease in vision. EyeRounds.org. 2013, Accessed: September 9, 2013: http://EyeRounds.org/cases/180-salzmann-nodular-corneal-degeneration.htm.

15. Garg D, Sharma D, Khan D: Salzmann's nodular degeneration right eye - a case report . J Med Sci Clin Res. 2019, 7:10. 10.18535/jmscr/v7i6.144

16. Yang MC, Al-Hashimi S, Rootman DB: Salzmann's nodular degeneration of cornea associated with thyroid eye disease. Orbit. 2019, 38:325-7. 10.1080/01676830.2018.1505921

17. Stem MS, Hood CT: Salzmann nodular degeneration associated with epithelial ingrowth after LASIK treated with superficial keratectomy. BMJ Case Rep. 2015, 6:207776. 10.1136/bcr-2014-207776

18. Lange AP, Bahar I, Sansanayudh W, Kaisermann I, Slomovic AR: Salzmann nodules -- a possible new ocular manifestation of Crohn's disease: a case report. Cornea. 2009, 28:85-6. 10.1097/ICO.0b013e3181814c90

19. Sinha R, Chhabra MS, Vajpayee RB, Kashyap S, Tandon R: Recurrent Salzmann's nodular degeneration: report of two cases and review of literature. Indian J Ophthalmol. 2006, 54:201-2. 10.4103/0301-4738.27075

20. Swann P, Shuley V: Case report: Salzmann's nodular degeneration. Clin Exp Optom. 1989, 72:148-9. 10.1111/j.1444-0938.1989.tb03075.x 